\title{
The influence of antioxidant on the productivity and activity of digestive broiler enzymes in reducing the risk of $\mathrm{T}-2$ toxin
}

\author{
V.R. Kairov ${ }^{1 \& 2}$, A.V. Kairov' ${ }^{1}$, M.G. Chabaev ${ }^{3}$, R.V. Nekrasov ${ }^{3}$, K.B. \\ Temiraev $^{4}$, E.F. Tsagaraeva ${ }^{5}$, L.A. Bobyleva ${ }^{6}$,
}

${ }^{1}$ Gorsky State Agrarian University, 362040, Vladikavkaz, 37 Kirov Street, Russian Federation;

${ }^{2}$ North Caucasian Research Institute of Mountain and Piedmont Agriculture - the Affiliate of Vladikavkaz Scientific Centre of the Russian Academy of Science, 363110, 1 Williams Str., Mihkailovskoe vil., Republic of North Ossetia - Alania, Russian Federation.

${ }^{3}$ Federal Science Center for Animal Husbandry named after Academy Member L.K. Ernst 142132,Moscow region, Podolsk City district, Dubrovitsy settlement, house 60, Russian Federation;

${ }^{4}$ Chair of Technology of Food Products, North-Caucasian Mining and Metallurgical Institute (State Technological University), Vladikavkaz 362021, Russian Federation.

${ }^{5}$ Chechen State Pedagogical University, City Grozniy, 364068, Russian Federation.

${ }^{6}$ North-Ossetian State University named after K.L. Khetagurov, Vladikavkaz, 362025, Russian Federation.

Journal of Livestock Science (ISSN online 2277-6214) 11: 85-89

Received on 29/1/20; Accepted on 2/4/2020

doi. 10.33259/JLivestSci.2020.85-89

\begin{abstract}
Recently, positive results have been achieved to reduce the risk of mycotoxicosis in meat poultry by rational use of various feed antioxidants, which inhibit processes of lipid peroxidation in the body and increase its immunity. The research aims to study the effect of different dosages of feed antioxidant Epofen on the basic economic and useful performance and digestive enzyme activity of broiler chickens grown on wheat-sorghumsunflower-based diets with tolerance level of T-2 toxin. To achieve this aim, the experiment using day-old "COBB500 " broiler chickens, which by the analogue scale were divided into 4 groups, was carried out on the poultry farm, agricultural production cooperative "Batraz", RNO - Alania. The resulting digital material was processed biometrically using the information program Excel. The research found that the best dose of feeding Epofen by reducing the risk of T-2 toxicosis in broilers is $200 \mathrm{~g} / \mathrm{t} \mathrm{feed,} \mathrm{which} \mathrm{improves} \mathrm{the} \mathrm{basic} \mathrm{economic} \mathrm{and} \mathrm{useful} \mathrm{qualities}$ and intensification of feed enzymolysis. At the same time versus counterparts from the control group, broilers in the second experimental group had increase in poultry stock safety by $4.0 \%$, gross and daily average gain - by $9.29 \%$ $(\mathrm{P}<0.05)$. Due to a better level of T-2 toxin detoxification by introducing preparation Epofen in mixed feed at a dose of $200 \mathrm{~g} / \mathrm{t}$ feed, in the muscular stomach content of meat chickens of the second experimental group was significant $(\mathrm{P}<0.05)$ increase in protease activity by $11.61 \%$, cellulase - by $19.93 \%$ and amylase - by $14.43 \%$. Also, the broilers of the second experimental group showed a significant $(\mathrm{P}<0.05)$ increase in the activity of proteinases in the chyme of the small intestine by $15.50 \%$. cellulase - by $14.19 \%$ and amylase - by $15.12 \%$.
\end{abstract}

Keywords: broiler; antioxidant; T-2 toxin; detoxification; live weight gain; activity of digestive enzymes. 


\section{Introduction}

In recent years, scientific research to reduce the risk of mycotoxicosis in meat poultry due to the use of biologically active additives in mixed feed that can remove or neutralize mold fungi toxins in the body is enriched. They are especially dangerous for broiler chickens because in the first days of life, due to the malformation of useful composition of microbiocenosis and the enzymatic link of the digestive system their immunity is still weak (Kisinov et al., 2005; Tsalieva et al., 2017; Lopatov, 1999).

Mold fungi especially heavily pollute grain components of poultry mixed feed in conditions of high humidity and violations of temperature-humidity storage conditions. Moreover, they begin to actively give off mold toxins - mycotoxins, which are very often resistant to high temperature, enzymatic treatment even when the fungusproducer is lost. Their danger is caused by the carcinogenic and mutagenic action of all known mold toxins, as well as the inhibitory action on the digestive enzymes and the growth rate of young birds (Temiraev et al., 2017; Temiraev et al., 2020; Tedtova et al., 2017).

One of the most resistant to various external factors of the mold are fungi Fusarium, which can actively contaminate grain ingredients of bird mixed feed with trichotecenes mycotoxin T-2 toxin (or "Yellow Rain"). When entering the bird's body, appear multiple symptoms of severe damage to its organs and tissues, primarily the lungs and stomach (Kokaeva, 2008; Temiraev et al., 2012; Baeva et al., 2013).

Recently, positive results have been achieved to reduce the risk of mycotoxicosis in meat poultry by rational use of various feed antioxidants, which inhibit processes of lipid peroxidation in the body and increase its immunity (Baeva et al., 2014; Kokaeva et al., 2017; Vityuk et al., 2017).

The research aims to study the effect of different dosages of feed antioxidant Epofen on the basic economic and useful performance and digestive enzyme activity of broiler chickens grown on wheat-sorghum-sunflowerbased diets with tolerance level of T-2 toxin.

\section{Material and methods}

To achieve the above stated aim in the conditions of the poultry farm, agricultural production cooperative

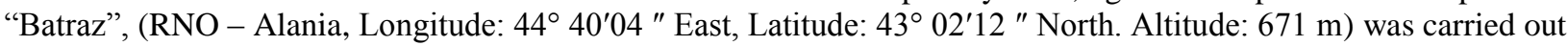
the experiment according to the scheme presented in table 1. The research objects were day-old "COBB-500" broiler chickens, which by the analogue scale were divided into four groups of 100 heads each.

When growing meat chickens, special poultry mixed feed PK-5 and PK-6 (Table 2) were used, the grain basis of which was represented by wheat grain, sorghum grain and sunflower meal. They were purchased from local manufacturers. Due to the use of standard feed dispensers the tolerance level of T-2 toxin $(0.1 \mathrm{mg} / \mathrm{kg}$ in accordance with GOST R 51899-2002) in used mixed feeds have been achieved by step mixing with environmentally friendly ingredients (Yesuf et al., 2017).

Poultry in compared groups was grown during 42 days, at this its weekly weighing was performed to determine body weight gain. At the same time the poultry stock safety was observed.

The tested feed supplement antioxidant Epophen in the organization of analogs of the experimental groups in the feed were injected by multi-stage mixing with the help of standard dispensers. Feed additive epophen is a natural analog of polyphenolic compounds of bioflavonoids in its structural structure. This additive is a new generation of domestic production (an effective antioxidant and antihypoxant), which has a structural similarity with a number of vitamins (E, K, PP). Epophen increases the intensity of tissue respiration, significantly optimizes energy and vitamin metabolism, inhibits the reaction of free radicals and toxins, removing some types of toxicants from the body. On the basis of experimental data, Z. T. Baeva (2009) recommends using the antioxidant Epophen in the diets of lactating cows with a subtoxic dose of nitrates in the amount of $3.0 \mathrm{~g} /$ head. (Sethy et al., 2017)

After the control slaughter, the activity of digestive enzymes in different sections of the gastrointestinal tract was studied in five birds from each group according to conventional methods (Fyodorov \& Kuzmin, 2013).

The resulting digital material was processed biometrically using the information program Excel.

Table 1 - Scheme of scientific and economic experiment on broilers $(n=100)$

\begin{tabular}{|l|l|}
\hline \multicolumn{1}{|c|}{ Cows group } & \multicolumn{1}{c|}{ Features of birds' feeding } \\
\hline Control & Basic diet with tolerance dose of T-2 toxin (BD) \\
\hline Experimental 1 & BD + Epofen at a dose of $100 \mathrm{~g} / \mathrm{t}$ feed \\
\hline Experimental 2 & BD + Epofen at a dose of $200 \mathrm{~g} / \mathrm{t}$ feed \\
\hline Experimental 3 & BD + Epofen at a dose of $300 \mathrm{~g} / \mathrm{t}$ feed \\
\hline
\end{tabular}


Table 2 - Composition and nutrition of feed for broiler chickens

\begin{tabular}{|c|c|c|}
\hline \multirow[t]{2}{*}{ Components, $\%$} & \multicolumn{2}{|c|}{ Recipe } \\
\hline & feed PK-5 & feed PK-6 \\
\hline Wheat & 40.0 & 42.5 \\
\hline Sorghum & 20.5 & 25.0 \\
\hline Sunflower meal & 15.5 & 15.0 \\
\hline Wheat bran & 3.0 & 5.0 \\
\hline Herbal flour & 2.0 & 2.0 \\
\hline Hydrolysis yeast & 6.0 & 3.4 \\
\hline Fish flour & 5.2 & 2.0 \\
\hline Feed fat & 1.0 & 1.0 \\
\hline Chalk feed & 2.0 & 1.0 \\
\hline Reverse dry & 2.5 & 0.2 \\
\hline Common salt & 0.3 & 1.0 \\
\hline Tricalcium phosphate & 2.0 & 0.9 \\
\hline Premix P6-1-89 & 1.0 & 1.0 \\
\hline \multicolumn{3}{|c|}{$100 \mathrm{~g}$ of feed contained: } \\
\hline exchange energy, MJ & 1297 & 1339 \\
\hline crude protein, $\mathrm{g}$ & 23.0 & 21.01 \\
\hline crude fat, $\mathrm{g}$ & 6.87 & 6.48 \\
\hline crude fiber, $\mathrm{g}$ & 4.02 & 4.03 \\
\hline calcium, $g$ & 1.05 & 1.21 \\
\hline phosphorus, $\mathrm{g}$ & 0.41 & 0.71 \\
\hline sodium, $\mathrm{g}$ & 0.21 & 0.20 \\
\hline lysine, $g$ & 1.27 & 0.84 \\
\hline methionine + cystine, $\mathrm{g}$ & 0.93 & 0.64 \\
\hline linoleic acid, $\mathrm{g}$ & 1.11 & 1.2 \\
\hline \multicolumn{3}{|l|}{ T-2 toxin, } \\
\hline For $1 \mathrm{t}$ of feed is added: methionine, $r$ & 600 & 700 \\
\hline
\end{tabular}

\section{Results and discussion}

In the course of the experiment during mycotoxins detoxification through feeding different doses of antioxidant Epofen, the stock safety, growth rate and feed efficiency in experimental meat chickens was studied (Table. 3).

It is found that the best higher productive effect was achieved when feed supplementing with Epofen at a dose of $200 \mathrm{~g} / \mathrm{t}$ feed. At this versus counterparts from the control group, broilers in the second experimental group had an increase of stock safety by $4.0 \%$, gross and daily average gain - by $9.29 \%(\mathrm{P}<0.05)$.

In the course of the experiment, it was found that versus control, due to the highest growth rate, the meat chickens in the second experimental group consumed mixed feed $9.00 \%$ less per unit of received gross formation. It shows that the best dose of Epofen feeding by reducing the risk of T-2 toxicosis in broiler-chickens is $200 \mathrm{~g} / \mathrm{t}$ feed, which improves the basic economic and useful qualities (Dzhaboeva et al., 2019; Kennedy et al., 2019)

To ensure high growth rate for broiler chickens, especially at the risk of mycotoxicosis, the problem of increasing the activity of digestive enzymes is of paramount importance, so we studied the effect of different antioxidant doses on the enzymes activity in the content of the muscular stomach (Table 4) and duodenum (Table 5).

Due to the best level of T-2 toxin detoxification due to the inclusion of the epofen preparation in feed at a dose of $200 \mathrm{~g} / \mathrm{t}$ of feed in the contents of the muscle stomach of meat chickens of the 2nd experimental group. a significant $(\mathrm{P}<0.05)$ excess of proteinase activity by $11.61 \%$. cellulase by $19.93 \%$ and amylase by $14.43 \%$.

The main part of the organic nutrients in feed is hydrolyzed and absorbed in the small intestine, so more attention was paid to the activity of endogenous enzymes in the duodenum chyme of experimental meat chickens. It is found that in the analyzed section of the intestine when feeding antioxidant Epofen at a dose of $200 \mathrm{~g} / \mathrm{t}$ feed by reducing risk of T-2 toxicosis in broiler chickens of the second experimental group there was significant $(\mathrm{P}<0.05)$ increase in the activity of proteases by $15.50 \%$, cellulase - by $14.19 \%$ and amylases - by $15.12 \%$ in the chyme of the small intestine.

Conclusion. At a tolerance level of T-2 toxin it is advisable to introduce antioxidant Epofen in wheatsorghum-sunflower-based mixed feed of broiler chickens at a dose of $200 \mathrm{~g} / \mathrm{t}$ feed to increase the stock safety, the 
live weight gain, feed conversion into production due to enzymatic hydrolysis of nutrients in different sections of the gastrointestinal tract.

Table 3 - Stock safety, growth rate and food conversion ratio in chickens

\begin{tabular}{|l|l|l|l|l|}
\hline \multirow{2}{*}{\multicolumn{2}{c|}{ Indicator }} & \multicolumn{4}{c|}{$\mathrm{n}=100$} \\
\cline { 2 - 5 } & Control & Experimental 1 & Experimental 2 & Experimental 3 \\
\hline Safety, \% & 91 & 93 & 95 & 94 \\
\hline Live weight per 1 head, g: & \multicolumn{4}{|c|}{} \\
\hline at the beginning of the experiment & $40.88+0.28$ & $40.79 \pm 0.31$ & $40.90 \pm 0.26$ & $40.87 \pm 0.30$ \\
\hline at the end of the experiment & $2381.42 \pm 5.9$ & $2529.71 \pm 5.5$ & $2599.31 \pm 6.2$ & $2543.65 \pm 4.9$ \\
\hline Body weight gain, g & \multicolumn{4}{|c|}{} \\
\hline gross & $2340.54 \pm 6.0$ & $2488.92 \pm 6.2$ & $2558.41 \pm 5.9$ & $2502.78 \pm 5.3$ \\
\hline daily average & $55.73 \pm 0.30$ & $59.26 \pm 0.19$ & $60.91 \pm 0.33$ & $59.59 \pm 0.29$ \\
\hline In \% to control & 100.00 & 106.33 & 109.29 & 106.93 \\
\hline Feed consumption per 1kg gain, $\mathrm{kg}$ & 2.00 & 1.88 & 1.82 & 1.86 \\
\hline
\end{tabular}

Table 4 - Enzymatic activity in the muscular stomach contents

\begin{tabular}{|l|c|c|c|c|}
\hline \multirow{2}{*}{\multicolumn{1}{|c|}{ Group }} & \multicolumn{4}{|c|}{ Enzymes activity, unit/g } \\
\cline { 2 - 5 } & proteinase & lipase & cellulase & amylase \\
\hline Control & $0.534 \pm 0.002$ & $0.564 \pm 0.014$ & $0.296 \pm 0.002$ & $0.627 \pm 0.002$ \\
\hline Experimental 1 & $0.578 \pm 0.003$ & $0.569 \pm 0.019$ & $0.322 \pm 0.002$ & $0.700 \pm 0.003$ \\
\hline Experimental 2 & $0.596 \pm 0.003$ & $0.560 \pm 0.013$ & $0.355 \pm 0.003$ & $0.717 \pm 0.003$ \\
\hline Experimental 3 & $0.581 \pm 0.002$ & $0.057 \pm 0.012$ & $0.233 \pm 0.004$ & $0.707 \pm 0.002$ \\
\hline
\end{tabular}

Table 5 - Enzymatic activity of the chyme of the duodenum

\begin{tabular}{|l|c|c|c|c|}
\hline \multirow{2}{*}{ Group } & \multicolumn{4}{|c|}{$\mathrm{n}=5$} \\
\cline { 2 - 5 } & proteinase & lipase & cellulase & amylase \\
\hline Control & $1.585 \pm 0.003$ & $1.638 \pm 0.006$ & $1.219 \pm 0.004$ & $1.720 \pm 0.004$ \\
\hline Experimental 1 & $1.795 \pm 0.003$ & $1.645 \pm 0.015$ & $1.381 \pm 0.003$ & $1.947 \pm 0.005$ \\
\hline Experimental 2 & $1.826 \pm 0.004$ & $1.633 \pm 0.014$ & $1.392 \pm 0.005$ & $1.980 \pm 0.004$ \\
\hline Experimental 3 & $1.802 \pm 0.003$ & $1.651 \pm 0.011$ & $1.387 \pm 0.005$ & $1.957 \pm 0.006$ \\
\hline
\end{tabular}

\section{References}

1) Baeva A.A., Ktsoeva I.I., Abaev A.V., Vityuk L.A., Kovaleva Yu.I., Payuchek V.G. 2014. Using Sorbents in Feeding for Increasing Environmental and Food Value of Broiler Meat. Scientific Journal of KubSAU (Polythematic online scientific journal of Kuban State Agrarian University) 101, no. 07: 2510-20.

2) Baeva A.A., Vityuk L.A., Abaeva S.K., Buzoeva L.B., Abaev A.V. 2013. Evaluation of Chicken Broiler's Meat when Disturbing the Nutritive Ecology. Izvestia of Gorky State Agrarian University 50, no. 2: 105-10.

3) Dzhaboeva A.S., Osepchuk D.V., Ashinov Y.N., Stolbovskaya A.A., Kochieva I.V., Khmelevskaya A.V., Bobyleva L.A., Temiraev R.B., Kokaeva M.G. 2019. Use of Thistle meal (Silybum marinum) as additive to improve nutritional and protective qualities of sausages. Journal of Livestock Science (ISSN online 22776214) 10:114-117 doi. 10.33259/JLivestSci.2019.114-117

4) Fyodorov M.V., Kuzmin E.A. 2013. Agriculture and Economic Security of Russia: Retrospective Research. Journal of International Scientific Researches 5, no. 1-2: 42-45

5) Kennedy O.O.O., Mbaba E.N., Iso, A. Halilu I.E., Robert A.N., A. N. \& B. Micheal 2019. Effects of turmeric rhizome powder on growth, carcass and meat quality of Japanese quails fed sorghum-soybean-based diets. Journal of Livestock Science (ISSN online 2277-6214) 11: 1-7. doi.10.33259/JLivestSci.2020.1-7

6) Kisinov, F.I., Temiraev, R.B., Tsogoeva, F.N. and Atarova, M.T. 2005. Selenium and tocopherol on the probiotic background. Poultry Farming. 10 : 21-22. 
7) Kokaeva M.G. 2008. Improving the Nutritional Value of Broiler Meat. Paper presented at the $12^{\text {th }}$ All-Russia scientific-practical conference "Agribusiness Industry and Topical Problems of Regions' Economy", in Maikop, Russia. 14-15 September 2008. Pg. 179-182

8) Lopatov S.M. Recommendations on Feeding Poultry by All-Russian Scientific-Research and Technology Institute of Poultry Industry (ARSRTIPI) of the Russian Academy of Agricultural Sciences. ARSRTIPI Publishing, 1999.

9) Sethy K., Swain P., Behera K., Sahoo N., Agrawalla J., Khadanga S., Mahapatra M.R. and Parhi S.S. 2017. Effect of turmeric (Curcuma longa) supplementation on antioxidants and immunity of broiler birds. Journal of Livestock Science (ISSN online 2277-6214) 8: 103-106

10) Tedtova, V.V., Kozhokov, M.K., Shugusheva, L.Kh., Kanukova, V.N., Baeva, A.A. and Vityuk, L.A. 2017. Preventive and detoxicative action of probiotics on metabolism and consumer quality of broilers meat. Journal of Pharmaceutical Sciences and Research. 9 (6) : 997-1001.

11) Temiraev, V.Kh., Kairov, V.R., Temiraev, R.B., Kubatieva, Z.A. and Gukezhev, V.M. 2017. Method to improve productive performance and digestion exchange of broiler chickens with reduced risk of aflatoxicosis. Ecology, Environment and Conservation. 23 (1) : 554-561.

12) Temiraev, R.B., Kokaeva, F.F., Tedtova, V.V., Baeva, A.A., Khadikova, M.A. and Abaev, A.V. 2012. Method for increasing the dietary meat quality and improvement of broilers metabolism in conditions of the industrial zone of North Ossetia - Alania. Proceedings of Gorsky State Agrarian University. Vladikavkaz. 49 (44) : 130-133.

13) Temiraev, R.B., Kozhokov, M.K., Cherchesova, S.K., Kokaeva, F.F. and Tletseruk, I.R. 2017. Method for diminishing the adverse effect of anthropogenic heavy metal pollution on poultry meat products. Journal of Environmental Management and Tourism. 8 (19) : 567-573.

14) Temiraev V.H., Baeva A.A., Vityuk L.A., Mamukaev M.N., Yurina N.A., Ktsoeva I.I., Bobyleva L.A., Zagaraeva E.F., Kokov T.N., Vologirova F.A. 2020. Effect of probiotics on digestive metabolism in growing and laying poultry birds. Journal of Livestock Science (ISSN online 2277-6214) 11: 33-39. doi. 10.33259/JLivestSci.2020.33-39

15) Vityuk, L.A., Baeva, A.A., Kochieva, I.V., Stolbovskaya, A.A., Kononenko, S.I., Yarmoc, A.V., Tletseruk, I.R., Bobyleva, L.A., Tsugkiev, B.G., Sattsaeva, I.K. 2017. Assessment of the productivity of broiler chicken sunder and the heavy metal detoxication in the context of industrial pollution. Pollution Research. 36 (4) : 748-754.

16) Yesuf K.Y., Mersso B.T., Bekele T.E. 2017. Effects of different levels of turmeric, fenugreek and black cumin on carcass characteristics of broiler chicken. Journal of Livestock Science (ISSN online 2277-6214) 8: 1117 